\title{
Inhibitory Effect on Arginase and Total Phenolic Content Determination of Extracts from Different parts of Melastoma malabathricum L.
}

\author{
Elin Novia Sembiring, Berna Elya*, Rani Sauriasari \\ Laboratory of Pharmacognosy and Phytochemistry, Faculty of Pharmacy, Universitas Indonesia, Depok 16424, West Java, INDONESIA.
}

\begin{abstract}
Background: Some phenolic compounds are potential source for arginase inhibitor that can be used in management of disease associated with endothelial dysfunction. Objective: The aim of this study was to investigate the inhibitory effect on arginase and to determine total phenolic content of extracts from different parts of Melastoma malabathricum L. Methods: Each part were extracted with $70 \%$ ethanol by maceration. The extracts were mixed with bovine liver arginase and L-arginine as a substrate. The inhibitory effect of extracts were determined in vitro, by measuring its absorbance on $430 \mathrm{~nm}$. Total phenolic content were determined with Folin-Ciocalteu $25 \%$ on $750 \mathrm{~nm}$. Results: The $70 \%$ ethanol extract of M. malabathricum leaves at $100 \mu \mathrm{g} / \mathrm{mL}$ was found to have highest inhibition $(81.26 \pm 5.27 \%)$ followed by flower $73.39 \pm 9.39 \%$, fruit $67.63 \pm 7.61$ and stem $61.61 \pm 4.56 \%$. The $I C_{50}$ value of the most active extract was $62.43 \mu \mathrm{g} / \mathrm{mL}$ while the $\mathrm{IC}_{50}$ value of $\mathrm{N}$-hidroksi-nor-Larginin (nor-NOHA) acetate, an arginase inhibitor was found to be $3.91 \mu \mathrm{g} / \mathrm{mL}$. Total phenolic content of $70 \%$ ethanolic extracts of M. malabathricum leaves, flower, fruit
\end{abstract}

and stem was $15.9,20.7,6.44$, and $6.29 \%$. Conclusion: The $70 \%$ ethanol extract of $M$. malabathricum leaves exhibited the highest inhibition on arginase but highest total phenolic content was from flower part. Pearson correlation test showed no correlation $p>0.05$ between arginase inhibition and total phenolic content of the samples.

Key words: Arginase, L-arginine, Melastoma malabathricum.

Correspondence

Berna Elya, Department of Pharmacognosy-Phytochemistry, Faculty of Pharmacy, Universitas Indonesia, Depok 16424 West Java, INDONESIA.

Phone: +62 81314161497

Email: berna.elya@farmasi.ui.ac.id, icapps2017.farmasiui@gmail.com

DOI: 10.5530/jyp.2018.2s.23

\section{INTRODUCTION}

Polyphenols are one of secondary metabolite in plants that have beneficial role on protective effect of cardiovascular system including improve endothelial function. ${ }^{1}$ Endothelial dysfunction is primarily due to reduction in Nitric Oxide (NO) bioavailabilty, impairment of endothelium- dependent vasorelaxation caused by a loss of nitric oxide bioactivity in the vessel wall. ${ }^{2}$ Endothelial dysfunction can result from and/or contribute to several disease development, as occured in hypertension, diabetes mellitus and hypercholesterolemia. ${ }^{1-2}$ Arginase is manganese metalloenzyme. ${ }^{3}$ Upregulation of Arginase can reduce the bioavailability of $\mathrm{NO}$ through competition between arginase with Nitric Oxide Syhthase (NOS) in using L-arginine as substrate, which can cause endothelial dysfunction. ${ }^{1-2}$ Potent inhibitor arginase such as $S$-(2- boronoethyl)-L-cysteine (BEC), 2-(S)-amino6-boronohexanoic acid $(\mathrm{ABH})$ ) and (omega)-hydroxy-nor-L-arginine (nor-NOHA) have some problem to be more developed. BEC and $\mathrm{ABH}$ might confer a potential toxicity and pharmacokinetic problem due to their boronic acid functionality. ${ }^{4}$ On the other hand, nor-NOHA have very short half-life. ${ }^{5}$ According to this fact, it is necessary to find arginase inhibitor from natural sources. Until now, study on arginase inhibitor from plants were still limited.

Previous study showed that phenolic compounds such as quercetin, kaempferol, epicatechin has inhibitory effect on bovine arginase with $\mathrm{IC}_{50} 31.2,179.1$, and $19.9 \mu \mathrm{g} / \mathrm{ml} .{ }^{1}$ Melastoma malabathricum containing those three phenolic compounds $s^{6}$ and other phenolic compounds so we hypothesized that extracts from different plant of this plant may have arginase inhibitory effects. The plant were also chosen based on their pharmacological effect on patogenesis some diseases related to upregulation of arginase such as hypertension, ${ }^{7-8}$ hyperlipidemia ${ }^{9}$ and wound healing. ${ }^{10}$ To test this hypotesis, we investigated the inhibitory effect on arginase of different parts of this plant using in vitro methods. According to literature search, inhibitory effect on arginase from these different parts of this plants have never been studied. In order to see the relationship between arginase inhibitory effect and polyphenolic content, total phenolic content of each extract was also determined.

\section{MATERIALS AND METHODS}

\section{Chemicals}

nor-NOHA acetate (Cayman, US), gallic acid (Sigma Aldrich, India), aqua bidestilata, bovine liver arginase (Sigma, Singapore), foline-ciocalteu (Merck, Germany), L-arginine (Sigma, Singapore), maleic acid (Sigma, Singapore), mangan sulfate (Sigma, Singapore), urea assay kit (Abnova, Taiwan), dimethyl sulfoxide (Merck, Germany).

\section{Plant materials}

Parts of M. malabathricum were collected in July 2017 from central of Kalimantan. Plants were identified by Indonesia Science Institution, Center for Plant Conservation-Bogor Botanical Garden, Indonesia.

\section{Preparation of samples}

The part of the plant were collected and cleaned, dried at room temperature, and then powdered and stored in an air tight glass container. $50 \mathrm{~g}$ of each plant part was extracted by maceration with $500 \mathrm{~mL}$ of $70 \%$ ethanol 
as the solvent in first day at room temperature, and continued macerated with $250 \mathrm{~mL}$ of $70 \%$ ethanol in second until fourth day. The extract then evaporated using a rotatory vacuum evaporator, and then dried in water bath on $50^{\circ} \mathrm{C}$.

\section{Determination of percent yield (\%)}

The extraction yield was calculated for each extract using the formula below :

$$
\text { Percent yield }(\%)=\mathrm{a} / \mathrm{b} \times 100
$$

(a) is dry weight of extract and (b) soaked samples material

\section{Arginase inhibition assay}

The inhibition of arginase activity was performed using the enzyme protocol (Sigma Aldrich) ${ }^{11}$ and urea assay kit obtained from Abnova Corporation, Taiwan (KA 1652) ${ }^{12}$ with slight modification. $N$-hidroksi-norL-arginin (nor-NOHA) acetate was used as the standard inhibitor. Briefly, $10 \mu \mathrm{L}$ of the $100 \mu \mathrm{g} / \mathrm{ml}$ extract solution, $15 \mu \mathrm{L}$ of arginase solution $(1 \mathrm{U} / \mathrm{mL})$ and $20 \mu \mathrm{L}$ L-arginine $570 \mathrm{mM}$ as the substrate of arginase, was added into the well. The mixture were shaked and incubated for $30 \mathrm{~min}$ at $37^{\circ} \mathrm{C}$ to have the complete reaction. In control wells the extract was replaced by dimethyl sulfoxide. The reaction was stopped by addition of $100 \mu \mathrm{L}$ of urea assay kit (kit $\mathrm{A}: \mathrm{kit} \mathrm{B}=1: 1$ ) into each well. The absorbance of urea was measured at $430 \mathrm{~nm}$ after incubation in room temperature $25^{\circ} \mathrm{C}$ for $60 \mathrm{~min}$, by a microplate reader (Versamax microplate reader, USA).

Percent of inhibition was calculated using the formula:

$$
\% \text { Inhibition }=\frac{([\mathrm{Abs} 1-\mathrm{Abs} 2]-[\mathrm{Abs} 3-\mathrm{Abs} 4])}{[\mathrm{Abs} 1-\mathrm{Abs} 2]} \times 100
$$

Abs1 is the absorbance of the control, Abs2 is the absorbance of the control blank, Abs3 is the absorbance of sample, and Abs4 is the absorbance of sample blank. $\mathrm{IC}_{50}$ value represents the concentration of inhibitor required to achieve $50 \%$ of enzyme inhibition.

\section{Phytochemical screening}

The qualitative phytochemistry test were conducted according to Indonesian Materia Medica ${ }^{13}$ and Harborne. ${ }^{14}$ Alkaloid test with Mayer, Dragendorff, and Bouchardat reagents; flavonoid test with Shinoda and Wilson Tauböck reaction; tannin test with gelatin test, gelatin-salt test, and test with ferrous (III) chloride; saponin test with foaming test; terpenoid test with Liebermann-Burchard reagent.

\section{Determination of total phenolic content}

Total phenolic content was determined using the 96-well microplate with Folin-Ciocalteu reagent, adapted from Ahmad et al. ${ }^{15}$ with slight modification. $20 \mu \mathrm{L}$ of the diluted extract or standard solution were added to $100 \mu \mathrm{L}$ of reagent $25 \%$ Foline-Ciocalteu and homogenized by shaken for $60 \mathrm{~s}$ in 96-well microplate, and then allowed to stand for $4 \mathrm{~min}$. After that, $75 \mu \mathrm{L}$ of sodium carbonate solution $(100 \mathrm{~g} / \mathrm{L})$ were added into the well and the mixture was shaken for 1 minute. After incubated for $2 \mathrm{~h}$ at room temperature, the absorbance was measured at $750 \mathrm{~nm}$ using the microplate reader (Versamax Microplate Reader). Extract or standard was substituted by ethanol as a blank. The standard curve for quantifying the phenolic contents was prepared by using gallic acid dilutions (6.25-200 mg/L). All samples were performed in triplicate.

\section{RESULTS}

The results showed that $70 \%$ ethanol extract of Melastoma malabathricum leaves gave the highest activity with percent inhibition of $81.26 \% \pm 5.27$
Table 1: In vitro arginase inhibition activity of different part of $M$. malabathricum.

\begin{tabular}{cccc}
\hline No. & Part of the plant & $\begin{array}{c}\text { Percent yield } \\
(\%)\end{array}$ & $\begin{array}{c}\text { Inhibition of Arginase } \\
(\%)\end{array}$ \\
\hline 1 & Stem & 8.44 & $61.61 \pm 4.56$ \\
2 & Fruit & 13.84 & $67.63 \pm 7.61$ \\
3 & Flower & 20.14 & $73.39 \pm 9.39$ \\
4 & Leaves & 18.1 & $81.26 \pm 5.27$ \\
\hline
\end{tabular}

Final concentration of the extract solution in the Arginase inhibition assay was $100 \mu \mathrm{g} / \mathrm{ml}$.

Data are mean \pm SEM for triplicate measurements.

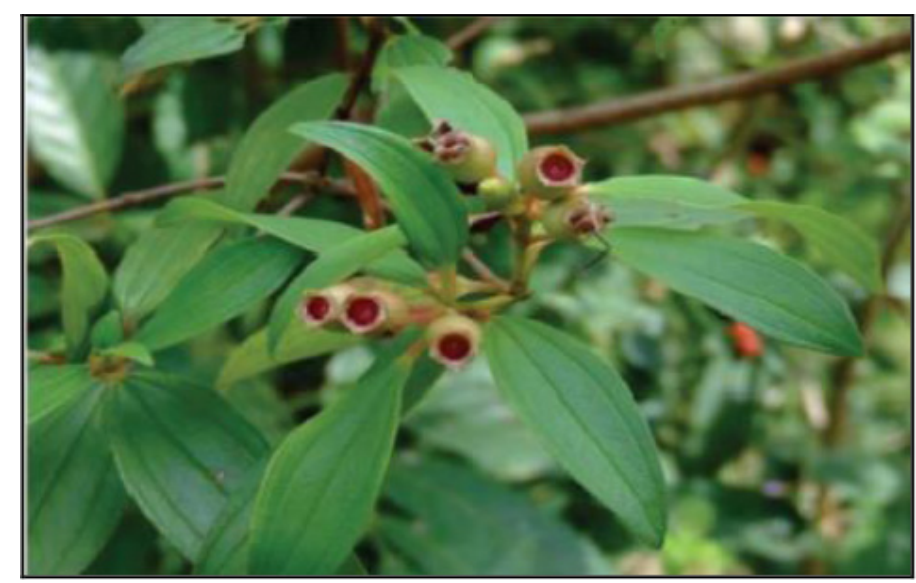

Figure 1: Melastoma malabathricum leaves ${ }^{6}$

(Table 1) and $\mathrm{IC}_{50} 62.43 \mu \mathrm{g} / \mathrm{mL}$ with equation $\mathrm{y}=0.8163 \mathrm{x}+0.9606$, $\mathrm{R}^{2}=0.9876$.

The leaves of Melastoma malabathricum as appears in Figure 1.

The extract was further investigated to determine the source of activity. The common phytochemistry content from plant such as flavonoid, alkaloid, terpenoid, steroid, tannin, and saponin have identified (Table 2).

\section{Total phenolic content}

The result of total phenolic content determination from $70 \%$ ethanolic extracts of Melastoma malabathricum leaves, flowers, stem and fruits extract are shown in Table 3. Calibration curve from gallic acid showed maximum absorbances at $750 \mathrm{~nm}$ wavelength (equation $\mathrm{y}=0.0655 \mathrm{x}+$ $0.045, \mathrm{R}^{2}=0.9931$ ). Total phenolic content of extracts could be ranked in the following order: M. malabathricum flower $>$ leaves $>$ fruits $>$ stem.

\section{DISCUSSION}

Investigated samples were successively extracted by maceration method using 70\% ethanol. Maceration method is cold extraction method by soaking raw materials for certain time in appropriate solvent. This method was chosen to avoid any degradation of any thermolabil active compounds during extraction which can caused by heat process. ${ }^{16-17} \mathrm{We}$ used $70 \%$ ethanol as solvent due to the polarity of polyphenol as target compound. ${ }^{18}$ as studied before that some phenolic compounds has arginase inhibitory activity. ${ }^{1}$ Some polar and semi polar compounds could be extracted by $70 \%$ ethanol. The inhibitory effect of three $70 \%$ ethanol extracts on arginase activity was performed with in vitro method using L-arginine as substrate. Arginase will hydrolized L-arginine to L-ornithine and urea. Those condition will be accomplished by cleaving the guanidino group from arginine. It converts one positively charged 
Table 2: Phytochemical screening of the extracts.

\begin{tabular}{ccccc}
$\begin{array}{c}\text { Phytochemical } \\
\text { Constituents }\end{array}$ & Stem & Fruit & Flower & Leaves \\
\hline Alkaloids & + & + & + & + \\
Flavonoid & + & + & + & + \\
Saponin & - & - & - & + \\
Terpenoids & + & + & + & + \\
Tannin & + & + & + & + \\
\hline
\end{tabular}

Note : - = absent, $+=$ present

Table 3: Total phenolic content of the extracts

\begin{tabular}{cc}
\hline Part of the plant & Total Phenolic Content (\%) \\
\hline Stem & 6.29 \\
Fruit & 6.44 \\
Flower & 20.7 \\
Leaves & 15.9 \\
\hline
\end{tabular}

Data are mean \pm SEM for triplicate measurements.

amino acid into another to yield urea. ${ }^{19}$ It is a colorimetric reaction of urea, o-phthalaldehyde, and $\mathrm{N}$-(1-naphthyl)ethylenediamme (NED). ${ }^{20}$ $\mathrm{N}$-(1-naphthyl)ethylenediamme (NED) could be replaced with primaquin ${ }^{21}$ in kit urea assay.

Prior to the arginase inhibition test of Nor-NOHA as positive control and extracts as samples, optimization of substrate concentration was done with concentration of enzyme $1 \mathrm{U} / \mathrm{mL}$, and some concentration of L-Arginine as substrat. The result showed that the optimum concentration of the substrate was at concentration of $570 \mathrm{mM}$. Based on this data, we chose L-arginin $570 \mathrm{mM}$ for further experiments. Extracts assay prepared by dilluted with dimethyl sulfoxide (DMSO) and aquabidestilata. Samples need to be mixed first with DMSO to assist the dissolution of the samples.

In this study, nor-NOHA acetat was used as positive control because nor-NOHA is one of the potent arginase inhibitor with $\mathrm{Ki} 500 \mathrm{mM} .^{22}$ Arginase inhibition by nor-NOHA was done by displacing the metal bridging hydroxide ion of arginase with $\mathrm{N}$-hydroxy group of nor-NOHA ${ }^{22}$ In current study, determination of $\mathrm{IC}_{50}$ of nor-NOHA acetate was done at concentration $1,2,3,4,5 \mu \mathrm{g} / \mathrm{mL}$. Ranging of concentration based on product information of nor-NOHA acetate that this compound exhibiting an $\mathrm{IC}_{50}$ value of $10-12 \mu \mathrm{M}$ or $2,963-3,556 \mu \mathrm{g} / \mathrm{mL}$. In some other research, studies of arginase inhibition of nor-NOHA not only tested using in vitro methods, but also developed to in vivo. Pre clinical trial in adult spontaneously hypertensive rats showed that Nor-NOHA decreases blood pressure and improves the reactivity of resistance vessels. ${ }^{23}$ Small scale clinical trial showed that nor-NOHA infusion increased endothelium-dependent vasodilatation in patients with coronary artery disease and diabetes mellitus type $2 .^{24}$

Arginase inhibition test on four samples showed that highest inhibitory effect was on Melastoma malabathricum leaf extract. Melastoma malabathricum in Indonesia known as senduduk, senggani, harendong or karamunting. ${ }^{6}$ Leaves of Melastoma malabathricum possessed antihypertensive ${ }^{25}$ wound healing activity. ${ }^{6}$ It contains some phenolic compound such as quercetin, ${ }^{6}$ epicathecin, epicathecin galat, kaempferol ${ }^{6,26}$ which is suspected as responsible compound for inhibitor of mamalia arginase ${ }^{1}$ also cinnamic acid derivate ${ }^{27}$ which can be also responsible for the inhibitory effect on arginase. ${ }^{28}$ These compound worked synergistically in the extract and showed higher arginase inhibitory effect on arginase than other Part extract of the plant. In other study, flavonol and epicatechin from Cocoa showed inhibition of arginase in HUVEC, ${ }^{29}$ Flavanone from
Scutellaria indica showed inhibition of arginase in mice kidney lisate. ${ }^{29}$ The result of total phenolic content of $M$. malabathricum flower extract showed highest phenolic content of this plant compared to other parts of plant extract. It can be considered that arginase inhibitor activity of this plant was not related with the high phenolic content. According to Thernier and $\mathrm{Pudlo}^{30}$ the catechol group suggested interacts with Asp 129 which is involved in metal bridge formation for the two $\mathrm{Mn}^{2+}$ cofactors in the site of arginase.

Total phenolic content determination from samples was measured using colorimetric method. Foline-Ciocalteu reagent use in this study was reacted with phenolic compound in the samples and created blue complex colour that could be read by the microplate reader.The relationship between the arginase inhibitory activity of extracts from different plant of M. malabathricum with their phenolic content was determined using pearson test correlation. The result indicated no correlation $(\mathrm{p}>0.05)$ between phenolic content of the samples with arginase inhibitory activity.

\section{CONCLUSION}

The current study indicate that $70 \%$ ethanolic extracts of Melastoma malabathricum (L). leaves exhibited highest arginase inhibitory activity among the three plant extracts,. This preliminary study could be used as early stage to develop arginase inhibitor from natural sources. Further study need to be carried out to identify the bioactive constituents.

\section{ACKNOWLEDGEMENT}

This study was supported by Universitas Indonesia via a grant "Hibah PITTA 2018”.

\section{CONFLICT OF INTEREST}

We declare that we have no conflict of interest.

\section{ABBREVIATIONS}

M. malabathricum: Melastoma malabathricum L.; IC $_{50}$ : Concentration of samples resulting in 50\% inhibition; nor-NOHA: N-hidroksi-nor-L arginin; DMSO : dimethyl sulfoxide.

\section{SUMMARY}

- $\quad$ Each part of M. malabathricum (flower, fruit, stem, leaves) were extracted by maceration using $70 \%$ ethanol as the solvent for 24 hours and repeated 3 times.

- $\quad$ The highest yield was flower (20.14\%).

- Phytochemical screening showed that all of samples

- positively contain flavonoid, alkaloid, terpenoid, tannin.

- Total phenolic content was the highest in flower (20.7\%) and the lowest in stem (6.29\%)

- The highest inhibition on arginase was in leaf extract (81.26 \pm $5.27 \%$ ) followed by flower, fruit and stem.

\section{REFERENCES}

1. Bordage S, Pham T, Zedet A, Gugglielmetti AS, Nappey M, Demougeot $C$. Investigation of mammal arginase inhibitory properties of natural ubiquitous polyphenols by using an optimized colorimetric microplate assay. Planta Med. 2017;83(07):647-53. http://dx.doi.org/10.1055/s-0042-118711.

2. Kolluru GK, Bir SC, Kevil CG. Endothelial dysfunction and diabetes: Effects on angiogenesis, vascular remodeling, and wound healing. International Journal of Vascular Medicine. 2012. Article ID 918267. P.1-30. doi:10.1155/2012/918267.

3. Kibiti CM, Afolayan AJ. Herbal therapy: A review of emerging pharmacological tools in the management of diabetes mellitus in Africa. Phcog Mag. 2015;11(S2):258-74.

4. Ivanenkov YA, Chufarova NV. Small-molecule arginase inhibitors. Pharm. Pat Anal. 2014;3(1):65-85. DOI: 10.4155/PPA.13.75. 
5. Havlinova Z, Babicova A, Hrosch M, Chladek J. Comparative pharmacokinetics of $\mathrm{N} \omega$-hydroxy-nor-L-arginine, an arginase inhibitor, after single-dose intravenous, intraperitoneal and intratracheal administration to brown Norway rats. Xenobiotica. 2013;43(10):886-94. DOI: 10.3109/00498254.2013.780672.

6. Joffry SM, Yob NJ, Rofiee MS, Affandi MM, Suhaili Z, Othman F, et al. Melastoma malabathricum (L.) Smith Ethnomedicinal Uses, Chemical Constituents, and Pharmacological Properties: A Review. Evidence-Based Complementary and Alternative Medicine. 2012:1-48. Article ID 258434. doi:10.1155/2012/258434.

7. Nelin LD, Stenger MR, Malleske DT, Chicoine LG. Vascular arginase and hypertension. Current Hypertension Reviews. 2007;3(4):242-9.

8. Michell DL, Andrews KL, Chin-dusting JP. Endothelial dysfunction in hypertension: The role of arginase. Frontiers in Bioscience. 2011;3:946-60.

9. Caldwell RB, Toque HA, Narayanan SP, Caldwell RW. Arginase : An old enzyme with new tricks. Trends in Pharmacological Sciences. 2015;36(6):395-405. http:// dx.doi.org/10.1016/j.tips.2015.03.006.

10. Kavalukas SL, Uzgare AR, Bivalacqua TJ, Barbul A. Arginase inhibition promotes wound healing in mice. Surgery. 2012;151(2):287-95. doi:10.1016/j.surg. 2011.07.012

11. Sigma-Aldrich Co. LLC. Enzymatic Assay of Arginase. 1997;St. Louis, Missouri: Author. 1997.

12. Abnova Corporation. Urea assay kit.Taoyuan: Author. 2007.

13. Departemen Kesehatan Republik Indonesia. Materia Medika Indonesia Jilid VI. 1995. (In Bahasa)

14. Harborne JB. Phytochemical methods A guide to modern techniques of plant analysis. Third ed. Chapman and Hall. 1998:204-8.

15. Ahmad I, Yanuar A, Mulia K, Mun'im A. Application of ionic liquid as a green solvent for polyphenolics content extraction of Peperomia Pellucida (L) Kunth Herb. J Young Pharm. 2017;9(4):486-90. DOI: 10.5530/jyp.2017.9.95.

16. Akowuah GA, Mariam A, Chin JH. The effect of extraction temperature on total phenols and antioxidant activity of Gynura procumbens leaf. Phcog Mag. 2009;5(17):81-5.

17. Oliveira FG, De Lima-Saraiva SR, Oliveira AP, Rabelo SV, Rolim LA, Almeida JR. Influence of the extractive method on the recovery of phenolic compounds in different parts of Hymenaea martiana hayne. Phcog Res. 2016;8(4):270-5.

18. Jing $L, M a H$, Fan P, Gao R, Jia Z. Antioxidant potential, total phenolic and total flavonoid contents of Rhododendron anthopogonoides and its protective effect on hypoxia-induced injury in PC12 cells. BMC Complementary and Alternative Medicine. 2015;15(1):287. DOI 10.1186/s12906-015-0820-3.
19. Jenkinson CP, Grody WW, Cederbaum SD. Comparative properties of arginases. Comparative Biochemistry and Physiology - B Biochemistry and Molecular Biology. 1996;114(1):107-32.

20. Jung D, Biggs $H$, Erikson J, Ledyard PU. New colorimetric reaction for end point, continuous flow, and kinetic measurement of urea. Clinical Chemistry. 1975;21(8):1136-40.

21. Zawada RJ, Kwan P, Olszweski KL, Llinas M, Huang S. Quantitative determination of urea concentrations in cell culture. Biochem Cell Biol. 2009;87(3):541-4. doi:10.1139/o09-011.

22. Steppan J, Nyhan D, Berkowitz DE. Development of novel arginase inhibitors for therapy of endothelial dysfunction. Frontiers in Imunology. 2013;4(278):1-6.

23. Bagnost T, Berthelot A, Bouhaddi M, Laurant P, Andre C, Guillaume Y, et al. Treatment with the arginase inhibitor Nv-hydroxy-nor-Larginine improves vascular function and lowers blood pressure in adult spontaneously hypertensive rat. Journal of Hypertension. 2008;26(6):1110-8.

24. Shemyakin A, Kovamees O, Rafnsson A, Bohm F, Svenarud P, Settergren M. Arginase inhibition improves endothelial function in patients with coronary artery disease and type 2 diabetes mellitus. Circulation. 2012;126(25):2943-50. DOI: 10.1161/CIRCULATIONAHA.112.140335.

25. Cheng J, Hsu F, Chen H. Antihypertensive Principles from the Leaves of Melastoma candidum. Planta Med. 1993;(59):405-7.

26. Sirat HM, Susanti $D$, Ahmad F, Takayama $H$, Kitajima M. Amides, triterpene and flavonoids from the leaves of Melastoma malabathricum L. J Nat Med. 2010;64(4):492-5. DOI 10.1007/s11418-010-0431-8.

27. Khoo LT, Abdullah JO, Abas F, Tohit ER, Hamid M. Bioassay-Guided Fractionation of Melastoma malabathricum Linn. Leaf Solid Phase Extraction Fraction and Its Anticoagulant Activity. Molecules. 2015;20(3):3697-715. doi:10.3390/ molecules20033697.

28. Pham T, Bordage S, Pudlo M, Demougeot C, Thai K, Girard-Thernier C. Cinnamide Derivatives as Mammalian Arginase Inhibitors: Synthesis, Biological Evaluation and Molecular Docking, International Journal of Molecular Sciences. 2016;17(10):1656. doi:10.3390/ijms17101656.

29. Girard-Thernier C, Pham TN, Demougeot C. The promise of plant-derived substances as inhibitors of arginase. Mini Rev Med Chem. 2015;15(10):798-808.

30. Pudlo M, Demougeot C, Girard-Thernier C. Arginase Inhibitors: A Rational Approach Over One Century. Medicinal Research Reviews. 2017;37(3):475-513. DOI 10.1002/med.21419.

Article History: Submission Date : 29-11-2017 ; Revised Date : 28-01-2018; Acceptance Date : 12-03-2018.

Cite this article: Sembiring EN, Elya B, Sauriasari R. Inhibitory Effect on Arginase and Total Phenolic Content Determination of Extracts from Different parts of Melastoma malabathricum L. J Young Pharm. 2018;10(2)Suppl:s114-s117. 